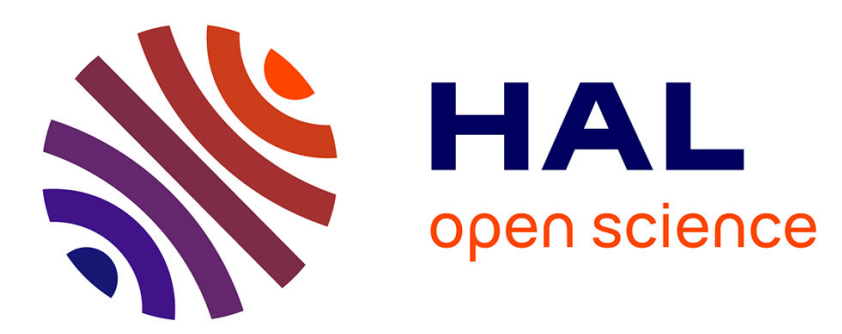

\title{
Relevance of intracellular partitioning of metals in prey to differential metal bioaccumulation among populations of mummichogs ()
}

\author{
Daisuke Goto, William G. Wallace
}

\section{- To cite this version:}

Daisuke Goto, William G. Wallace. Relevance of intracellular partitioning of metals in prey to differential metal bioaccumulation among populations of mummichogs (). Marine Environmental Research, 2009, 68 (5), pp.257. 10.1016/j.marenvres.2009.06.015 . hal-00563090

\author{
HAL Id: hal-00563090 \\ https://hal.science/hal-00563090
}

Submitted on 4 Feb 2011

HAL is a multi-disciplinary open access archive for the deposit and dissemination of scientific research documents, whether they are published or not. The documents may come from teaching and research institutions in France or abroad, or from public or private research centers.
L'archive ouverte pluridisciplinaire HAL, est destinée au dépôt et à la diffusion de documents scientifiques de niveau recherche, publiés ou non, émanant des établissements d'enseignement et de recherche français ou étrangers, des laboratoires publics ou privés. 


\section{Accepted Manuscript}

Relevance of intracellular partitioning of metals in prey to differential metal bioaccumulation among populations of mummichogs (Fundulus heteroclitus)

Daisuke Goto, William G. Wallace

PII: S0141-1136(09)00085-3

DOI: 10.1016/j.marenvres.2009.06.015

Reference: MERE 3354

To appear in: Marine Environmental Research

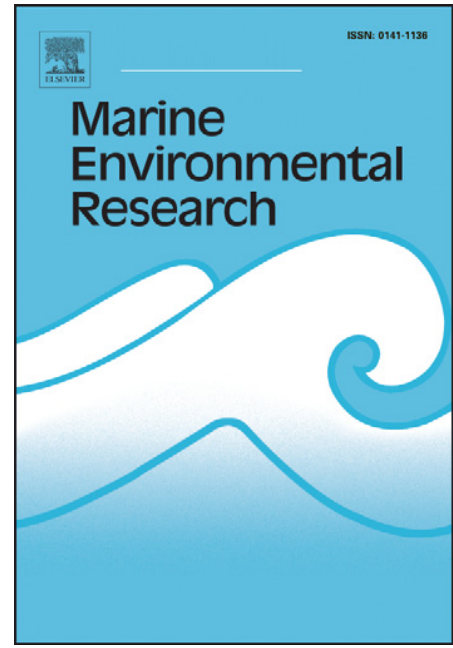

Received Date: $\quad 29$ May 2009

Revised Date: $\quad 18$ June 2009

Accepted Date: $\quad 24$ June 2009

Please cite this article as: Goto, D., Wallace, W.G., Relevance of intracellular partitioning of metals in prey to differential metal bioaccumulation among populations of mummichogs (Fundulus heteroclitus), Marine Environmental Research (2009), doi: 10.1016/j.marenvres.2009.06.015

This is a PDF file of an unedited manuscript that has been accepted for publication. As a service to our customers we are providing this early version of the manuscript. The manuscript will undergo copyediting, typesetting, and review of the resulting proof before it is published in its final form. Please note that during the production process errors may be discovered which could affect the content, and all legal disclaimers that apply to the journal pertain. 


\section{Relevance of intracellular partitioning of metals in prey to differential metal bioaccumulation among populations of mummichogs (Fundulus heteroclitus)}

Daisuke Goto $^{\mathrm{a}, *}$

William G. Wallace

${ }^{a}$ Biology Program

Graduate School and University Center

City University of New York

365 Fifth Avenue

New York, New York 10016, USA

${ }^{\mathrm{b}}$ Biology Department

College of Staten Island, 6S-310

City University of New York

2800 Victory Boulevard

Staten Island, New York 10314, USA

email: wallace@mail.csi.cuny.edu

*Corresponding author

email: daisukegoto@att.net

phone: + 1 (718) 982-3924

fax: + 1 (718) 982-3923 


\begin{abstract}
Intracellular partitioning of trace metals is critical to metal tolerance in aquatic organisms and may also influence metal trophic transfer in ecosystems. In this study, we tested the relevance of metal $(\mathrm{Cd}, \mathrm{Cu}, \mathrm{Pb}$, and $\mathrm{Zn})$ intracellular partitioning in prey as an indicator of metal trophic availability to benthic forage fish, mummichogs (Fundulus heteroclitus), in chronically metal-polluted salt marshes in New York, USA. Two common prey of mummichogs in the study area, Palaemonetes pugio and Nereis acuminata, generally stored increasingly higher proportions of non-essential metals (particularly $\mathrm{Pb}$ ) in insoluble (less trophically available) cellular components, as the whole body burdens increased. In contrast, intracellular partitioning of essential metals $(\mathrm{Cu}$ and $\mathrm{Zn})$ in invertebrate prey varied relatively little among sites. Differential $\mathrm{Cd}$ and $\mathrm{Pb}$ intracellular partitioning patterns within $P$. pugio among sites were significantly associated with $\mathrm{Cd}$ and $\mathrm{Pb}$ whole body burdens in mummichogs, respectively (i.e., prey-driven bioreduction of metals), while bioaccumulation of $\mathrm{Cu}$ and $\mathrm{Zn}$ in mummichogs was similar among populations. The findings in this study suggest that metal intracellular partitioning within prey may be partially responsible for metal trophic availability to a predator in metalpolluted habitats, while there was also evidence that some predator-dependent processes may offset differential trophic availabilities from prey.
\end{abstract}

Key words: Metals; zoobenthos; forage fish; salt marshes; metal trophic transfer; metal intracellular partitioning; Fundulus heteroclitus; New York, USA 


\section{Introduction}

In the past decade, an increasing number of studies have explored ecological and evolutionary implications for intracellular partitioning of trace metals within aquatic organisms in chronically polluted habitats (e.g., Martin et al., 2007; Perceval et al., 2004). Chronic trace metal pollution can exert selection pressure on organisms (Klerks and Weis, 1987; Luoma, 1977), ultimately eliminating local populations of metal-sensitive species and allowing metaltolerant species to dominate biological communities (Clements, 1997). Differential tolerance to trace metals among populations or species is often associated with intracellular metal storage within aquatic organisms (e.g., Buchwalter et al., 2007; Perceval et al., 2004). Metal-tolerant species generally possess physiological or biochemical mechanisms that allow them to cope with an elevated level of bioavailable trace metals in the environment (Mason and Jenkins, 1995).

These mechanisms include sequestration to metal-binding proteins (e.g., metallothioneins) (Mason and Jenkins, 1995; Roesijadi, 1992) and formation of granular concretions (or metal-rich granules) (Klerks and Bartholomew, 1991; Mason and Jenkins, 1995).

Experimental studies have demonstrated that intracellular partitioning of trace metals in prey can also influence metal trophic availability to their predators (e.g., Cheung and Wang, 2005; Wallace and Luoma, 2003). The importance of dietary ingestion of trace metals as a predominant route for metal bioaccumulation in aquatic organisms has been well documented (e.g., Griscom et al., 2002; Wang, 2002). Trace metals accumulated in prey can be transferred to and potentially cause secondary toxic effects in their predators (Baines et al., 2002; Ni et al., 2000). Differential intracellular partitioning of trace metals among chronically metal-exposed populations or species may thus have important implications for ecological impacts that cascade through food chains in ecosystems. 
The relevance of intracellular metal distributions within prey to metal trophic transfer results from differential trophic availabilities of metals distributed among various cellular components (Wallace and Lopez, 1997; Zhang and Wang, 2006). As trace metals bound to organelles and cytosolic proteins (including metal-binding proteins) are readily solubilized by the digestive processes of a predator, metals associated with these cellular components are thought to be more available to a predator than those with other components (Wallace and Lopez, 1997; Zhang and Wang, 2006). Due to their high bioavailabilities to predators, Wallace and Luoma (2003) have suggested that metals associated with cytosolic proteins and organelles within prey be compartmentalized as 'trophically available metal' (TAM). In contrast, trace metals partitioned to insoluble components such as metal-rich granules within prey are not readily available to many predators, as most granules are not easily solubilized by the digestive processes (Nott and Nicolaidou, 1994; Wallace and Lopez, 1997). The majority of trace metals sequestered into granules within prey can pass through the digestive tract of a predator without being assimilated (Rainbow et al., 2004; Wallace and Lopez, 1997). Determining intracellular partitioning of trace metals within prey may, therefore, be used to 1) understand specific metal trophic pathways and 2) estimate the extent of potential metal trophic transfer efficiency when assessing ecological impacts associated with trace metal pollution.

In the present study, we tested the relevance of metal intracellular partitioning in prey as an indicator of differential metal trophic availability to mummichogs, Fundulus heteroclitus (Pisces: Cyprinodontidae), in metal-polluted tidal salt marshes in New York, USA. Mummichogs are among the most abundant fishes in tidal creeks and salt marshes in the northwest Atlantic coast (Nixon and Oviatt, 1973). Like many benthic predators, mummichogs primarily feed on a variety of benthic macroinvertebrates (Kneib et al., 1980), which are in direct contact with sediments 
(the main source of trace metals in benthic food chains). Elevated levels of sediment-associated trace metals have persistent and cumulative effects, inducing various ecological and physiological alterations in marine organisms living in urban coastal habitats (Luoma, 1996). Furthermore, mummichogs play an essential role as an intermediate predator linking sedimentassociated invertebrates to piscivorous fishes and wading birds using tidal salt marshes and inland wetlands as feeding grounds (Kneib and Wagner, 1994). Understanding factors determining the extent of metal trophic availability to mummichogs (a conduit of trace metal transfer to top predators) would, therefore, provide much needed information on potential ecological impacts of trace metal pollution in urban coastal ecosystems.

\section{Materials and methods}

\subsection{Study area}

This study was conducted in the Arthur Kill-AK (part of the New York/New Jersey-NY/NJ Harbor Estuary Complex), which is a tidal waterway located between northern NJ and Staten Island, NY, connecting Newark Bay and Kill van Kull to the north, and Raritan Bay, NY Harbor, and the Atlantic Ocean to the south (Fig. 1). Due to chronic pollution (e.g., chemical discharges from industrial facilities and sewage treatment plants), the water quality of the NY/NJ Harbor Estuary has been severely degraded for more than a century (Crawford et al., 1994). The highest levels of some chemical pollutants occur in tributaries of AK (Weis et al., 2001). Since tides enter from both ends of AK (Fig. 1), this region is poorly flushed, resulting in enhanced entrapment and accumulation of pollutants in sediments (Bopp et al., 2006).

Specific study sites were four tributaries of AK; Richmond Creek, Main Creek, Neck Creek, and Mill Creek and two regional reference sites external to AK; Lemon Creek and Great Kills 
Harbor (Fig. 1 and Table 1). Neck Creek is polluted with various chemicals due to its proximity to many oil refineries as well as abandoned industrial facilities (Ward, 2002). Richmond Creek and Main Creek are tributaries of Fresh Kills Complex and are surrounded by the Landfill. Mill Creek is located near the confluence of AK and Raritan Bay and has been polluted from historic smelting activities in the area. Lemon Creek is one of a few relatively undisturbed tidal salt marshes in the region. Despite its proximity to sewage treatment plants, Great Kills Harbor, which is located on the eastern shore of Staten Island, has relatively low levels of most pollutants.

\subsection{Samplings of mummichogs and benthic macroinvertebrate prey}

Samplings of mummichogs and two of the most commonly consumed prey items of mummichogs in AK, decapods (Palaemonetes pugio) and polychaetes (Nereis acuminata) (Goto, 2009), were conducted during the summers (June to September) of 2001 and 2004. Large adult mummichogs (> $70 \mathrm{~mm}$ TL) were collected using a seine net with polyester mesh or cylindrical minnow trap. N. acuminata was collected by sieving bulk sediments through a $500 \mu \mathrm{m}-\mathrm{mesh}$ sieve, while adult $P$. pugio (> 25 mm TL) was collected using a D-frame dip net. Mummichogs, $P$. pugio, and N. acuminata were then transported on ice to laboratory.

\subsection{Laboratory sample processing of mummichogs and benthic macroinvertebrate prey}

In the laboratory, mummichogs and macroinvertebrates were allowed to depurate gut contents for at least 24 hours in filtered $15 \%$ o seawater. Mummichogs were then immediately euthanized by an overdose of MS222. Macroinvertebrates and mummichogs were then stored in a freezer $\left(-80^{\circ} \mathrm{C}\right)$ for subsequent fractionation and/or metal analyses (Sections 2.4 and 2.5). 


\subsection{Isolation of TAM from benthic macroinvertebrate prey}

Trace metals associated with the trophically available metal (TAM) compartment were isolated from $P$. pugio and $N$. acuminata using a centrifugation technique (Wallace and Luoma, 2003). Macroinvertebrates ( $n=5$ per site for prey species; each sample $=\sim 500 \mathrm{mg}$ of tissues) were thawed on ice, dabbed dry, and weighed. Tissues were then transferred into pre-weighed centrifuge tubes and homogenized (under a nitrogen atmosphere) in cold TRIS buffer (20 mM, $\mathrm{pH}=7.6$ ) with a Polytron tissue homogenizer (Kinematica, Luzern, Switzerland) (Wallace and Luoma, 2003). The homogenates were fractionated by centrifugation at $1,450 \mathrm{x} g$ for 15 minutes, which produced a pellet containing tissue fragments and cellular debris, and a supernatant containing cytosolic proteins and organelles (i.e., TAM) (Wallace and Luoma, 2003). Each fraction was processed for metal analyses, as described below (Section 2.5).

\subsection{Analyses of metals in mummichogs and benthic macroinvertebrate prey}

Resultant supernatants and pellets from fractionated macroinvertebrates as well as a whole body of mummichogs were oven-dried $\left(\sim 70{ }^{\circ} \mathrm{C}\right)$ for 24 to 48 hours and weighed (dry weight). Samples were then digested under reflux with concentrated Trace Metal Grade nitric acid (5 ml) overnight at room temperature $\left(\sim 20^{\circ} \mathrm{C}\right)$ and subsequently on a hotplate $\left(\sim 80{ }^{\circ} \mathrm{C}\right)$ for $\sim 48$ to 72 hours. Once digested, samples were evaporated to dryness, re-suspended in $2 \%$ nitric acid (8 ml), and filtered $(0.45 \mu \mathrm{m})$. Metal concentrations in samples were analyzed with graphite furnace atomic absorption spectrometer for cadmium $(\mathrm{Cd})$, copper $(\mathrm{Cu})$, and lead $(\mathrm{Pb})$, or flame atomic absorption spectrophotometer for zinc (Zn) (Perkin Elmer 3100AAS with AS-60). 
As quality assurance, Standard Reference Material ${ }^{\circledR}$ (mussel tissue, SRM 2976, National Institute of Standards and Technology, USA) was processed and analyzed for $\mathrm{Cd}, \mathrm{Cu}, \mathrm{Pb}$, and $\mathrm{Zn}$, as described above. The average recovery rates of $\mathrm{Cd}, \mathrm{Cu}, \mathrm{Pb}$, and $\mathrm{Zn}$ were 95.3, 100.3, 63.5, and $96.3 \%$, respectively. Procedural and reagent blanks were also analyzed for potential secondary metal contamination. Select calibration standard solutions of each metal were analyzed every 10 samples. When the deviation from the initial values was more than $\pm 10 \%$, the instrument was recalibrated. The correlation coefficients of calibration curves were maintained > 0.999 for the analysis. All standard solutions and samples were prepared with NANOpure ${ }^{\circledR}$ (reagent-grade) water. All glassware was soaked in $10 \%$ hydrochloric acid overnight, rinsed once with deionized water, and rinsed twice with NANOpure ${ }^{\circledR}$ water.

\subsection{Statistical analyses}

The normality of data was tested using Shapiro-Wilk's $W$ test. The homogeneity of variance was tested using Levene's test. Proportional data were arcsine-transformed, and concentration data were $\log _{10}$-transformed before analyses, when necessary. The statistical significance of differences in whole body burdens of mummichogs among populations was tested using one-way analysis of variance (ANOVA), which, if significant, was followed by Tukey's honestly significant difference (HSD) test. Relationships between trace metals associated with TAM and whole body burdens in $P$. pugio and $N$. acuminata were analyzed with linear and nonlinear regressions, which were fitted by the Levenberg-Marquardt least squares algorithm. As all variables were subject to measurement error, relationships between trace metals associated with TAM in P. pugio or $N$. acuminata and whole body burdens in mummichogs were analyzed with 
reduced major axis (RMA) or model II regression (Sokal and Rohlf, 1995). All statistical analyses were performed using Statistica 7.1 (Statsoft, Inc $\left.{ }^{\circledR}, \mathrm{USA}\right)$.

\section{Results}

\subsection{Intracellular partitioning of trace metals to TAM in prey}

The concentration of $\mathrm{Cd}$ partitioned to the trophically available metal (TAM) compartment (TAM-[Cd]) was significantly correlated with Cd whole body burden (WB-[Cd]) in Palaemonetes pugio in both 2001 and 2004 (Fig. 2a and 2b, respectively). Although there was a significant correlation between the proportion of Cd associated with TAM (TAM-Cd\%) and WB-[Cd] in $P$. pugio in 2001, TAM-Cd\% in $P$. pugio was approximately $40 \%$ of WB-[Cd] at all sites (Fig. 2c). In 2004, there was no relationship between TAM-Cd\% ( 60\%) and WB-[Cd] in P. pugio (Fig. 2d).

In Nereis acuminata, there was a significant correlation between TAM-[Cd] and WB-[Cd] in both 2001 and 2004 (Fig. 2e and 2f, respectively) with a disproportionately low TAM-[Cd] at

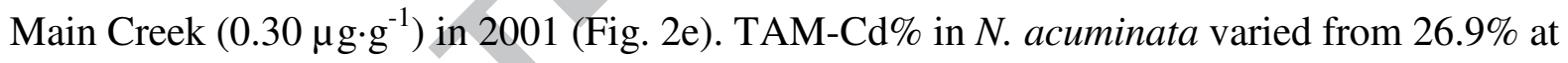
Main Creek to $74.8 \%$ at Great Kills Harbor and was negatively correlated with WB-[Cd] in 2001 (Fig. 2g). In 2004, however, there was no relationship between TAM-Cd\% and WB-[Cd] in $N$. acuminata (Fig. 2h).

The concentration of $\mathrm{Pb}$ in TAM (TAM- $[\mathrm{Pb}])$ in $P$. pugio was significantly correlated with the $\mathrm{Pb}$ whole body burden (WB-[Pb]) in both 2001 and 2004 (Fig. 3a and 3b, respectively). The proportion of $\mathrm{Pb}$ in TAM (TAM- $\mathrm{Tb} \%$ ) in $P$. pugio was negatively correlated with $\mathrm{WB}-[\mathrm{Pb}]$ in both 2001 and 2004 (Fig. 3c and 3d, respectively). In 2001, TAM-Pb\% in P. pugio varied from 25\% at Neck Creek and Richmond Creek to $63.9 \%$ at Great Kills Harbor (Fig. 3c), while in 
2004, TAM-Pb\% in P. pugio varied from $34.8 \%$ at Mill Creek to $~ 52 \%$ at Lemon Creek, Richmond Creek, and Great Kills Harbor (Fig. 3d).

In N. acuminata, both TAM-[Pb] and TAM-Pb\% were significantly correlated with $\mathrm{WB}-[\mathrm{Pb}]$ in 2001 (Fig. 3e and 3g, respectively). Despite its high WB-[Pb], TAM-[Pb] and TAM-Pb\% in N. acuminata at Main Creek were disproportionately lower than those at the other sites. In 2004, both TAM-[Pb] and TAM-Pb\% were also significantly correlated with WB-[Pb] (Fig. 3f and 3h, respectively) but varied relatively little among sites.

Significant correlations were observed between the concentration of $\mathrm{Cu}$ in TAM (TAM-[Cu]) and the $\mathrm{Cu}$ whole body burden (WB-[Cu]) in P. pugio in both 2001 and 2004 (Fig. 4a and 4b, respectively). The proportion of $\mathrm{Cu}$ associated with TAM (TAM-Cu\%) in $P$. pugio remained relatively constant $(\sim 80 \%)$ across the sites in 2001 , with the exception of Mill Creek $(\sim 60 \%)$, resulting in no relationship with WB-[Cu] (Fig. 4c). Similarly, in 2004, although TAM-Cu\% was significantly correlated with WB-[Cu] in $P$. pugio, it generally remained $\sim 80 \%$ at all sites (Fig. 4d).

In N. acuminata, TAM- $[\mathrm{Cu}]$ was significantly correlated with $\mathrm{WB}-[\mathrm{Cu}]$ in both 2001 and 2004 (Fig. 4e and 4f, respectively), but TAM-[Cu] at Main Creek in 2001 was disproportionately low (Fig. 4e). In both 2001 and 2004, there was no clear relationship between TAM-Cu\% and WB-[Cu] in N. acuminata (Fig. 4g and 4h, respectively).

Although both the concentration and proportion of $\mathrm{Zn}$ associated with TAM (TAM-[Zn] and TAM-Zn\%, respectively) were significantly correlated with the $\mathrm{Zn}$ whole body burden (WB[Zn]) in $P$. pugio, both TAM-[Zn] and TAM-Zn\% in $P$. pugio were generally similar among sites (40 to $60 \mu \mathrm{g} \cdot \mathrm{g}^{-1}$ and $\sim 60 \%$, respectively) (Fig. 5a and 5b). In N. acuminata, TAM-[Zn] was 
significantly correlated with WB-[Zn] (100 to $180 \mu \mathrm{g} \cdot \mathrm{g}^{-1}$ ) (Fig. 5c), while TAM-Zn\% in $N$. acuminata remained relatively constant ( 60\%) across the sites (Fig. 5d).

\subsection{Metal bioaccumulation in mummichogs}

In 2001, there were significant differences in whole body burdens of $\mathrm{Cd}, \mathrm{Pb}, \mathrm{Cu}$, and $\mathrm{Zn}$ in mummichogs among populations (one-way ANOVA, Table 2). The whole body burdens of Cd varied from $0.03 \mu \mathrm{g} \cdot \mathrm{g}^{-1}$ at Richmond Creek to $0.10 \mu \mathrm{g} \cdot \mathrm{g}^{-1}$ at Great Kills Harbor (Table 2). The whole body burdens of $\mathrm{Pb}$ varied from $\sim 0.25 \mu \mathrm{g} \cdot \mathrm{g}^{-1}$ at Great Kills Harbor and Richmond Creek to $\sim 0.90 \mu \mathrm{g} \cdot \mathrm{g}^{-1}$ at Neck Creek, Main Creek, and Mill Creek (Table 2). The whole body burdens of $\mathrm{Cu}$ were similar among sites $\left(\sim 8 \mu \mathrm{g} \cdot \mathrm{g}^{-1}\right)$, except for that at Neck Creek $\left(18.5 \mu \mathrm{g} \cdot \mathrm{g}^{-1}\right)$ (Table 2). The whole body burdens of $\mathrm{Zn}$ varied from $\sim 140 \mu \mathrm{g} \cdot \mathrm{g}^{-1}$ at Lemon Creek, Main Creek, and Richmond Creek to $193.7 \mu \mathrm{g} \cdot \mathrm{g}^{-1}$ at Neck Creek (Table 2).

In 2004, there was no significant difference in whole body burdens of metals in mummichogs among populations (Cd: $\sim 0.04 \mu \mathrm{g} \cdot \mathrm{g}^{-1}$; $\mathrm{Cu}: \sim 10 \mu \mathrm{g} \cdot \mathrm{g}^{-1} ; \mathrm{Zn}: \sim 166 \mu \mathrm{g} \cdot \mathrm{g}^{-1}$, Table 2), except for $\mathrm{Pb}$. The $\mathrm{Pb}$ whole body burden in mummichogs from Mill Creek was significantly higher $\left(1.45 \mu \mathrm{g} \cdot \mathrm{g}^{-}\right.$

${ }^{1}$ ) than those from the other sites $\left(\sim 0.6 \mu \mathrm{g} \cdot \mathrm{g}^{-1}\right)$ (Tukey's HSD test, Table 2$)$.

\subsection{Relationship between TAM in prey and metal bioaccumulation in mummichogs}

Significant relationships with whole body burdens of metals in mummichogs were observed only for $P$. pugio TAM-[Pb] in $2001\left(\mathrm{WB}-[\mathrm{Pb}]_{\text {fish }}=6.42\right.$ TAM- $[\mathrm{Pb}]_{\text {prey }}+0.11$, Fig. $\left.6 \mathrm{a}\right)$ and $P$. pugio TAM- $[\mathrm{Cd}]$ in $2004\left(\mathrm{WB}-[\mathrm{Cd}]_{\mathrm{fish}}=0.97\right.$ TAM- $[\mathrm{Cd}]_{\text {prey }}+7.05$, Fig. 6b). In both of these cases, WB- $[\mathrm{Pb}]_{\text {prey }}$ and $\mathrm{WB}-[\mathrm{Cd}]_{\text {prey }}$ in $P$. pugio were randomly distributed without any 
consistent relationship with $\mathrm{WB}-[\mathrm{Pb}]_{\text {fish }}$ and $\mathrm{WB}-[\mathrm{Cd}]_{\text {fish }}$ in mummichogs, respectively (Fig. 6a and 6b).

\section{Discussion}

The relevance of metal intracellular partitioning to metal tolerance has been increasingly recognized for various marine and freshwater organisms in metal-polluted habitats (e.g., Campbell et al., 2005; Mouneyrac et al., 2003). Some experimental studies have indicated that metal detoxification strategies used by prey can influence metal trophic transfer (e.g., Rainbow et al., 2006b; Wallace et al., 1998). Despite the importance of dietary exposure to trace metals (Farag et al., 1999; Woodward et al., 1995), however, secondary implications of metal intracellular partitioning in prey to their predators (e.g., metal trophic transfer) have not been fully explored in the field setting. Although there have been many field studies on metal pollution impacts on fish (e.g., metal bioaccumulation and toxicity) in marine and freshwater ecosystems, these studies often focus on whole body burdens (e.g., Clements and Rees, 1997; Farag et al., 1999). Whole body burdens are, however, often not informative in understanding differential metal pollution impacts on fishes and shellfishes (Clements and Rees, 1997; Farag et al., 1999). Farag et al. (1999) have, for example, demonstrated that metals accumulated in macroinvertebrate prey from an intermediately polluted site in Coeur d'Alene River (Idaho, USA) were more bioavailable and subsequently caused stronger toxic effects in cutthroat trout (Oncorhynchus clarki) than those from a highly polluted site (Farag et al., 1999).

The results from the current study indicated that metal intracellular partitioning in an omnivorous decapod (Palaemonetes pugio) and a deposit-feeding polychaete (Nereis acuminata) in the Arthur Kill-AK were highly species- and metal- specific. For instance, although sediment- 
associated cadmium (Cd) levels in the AK sites were relatively low ( 2.4 to $6.0 \mu \mathrm{g} \cdot \mathrm{g}^{-1}$, Table 1$)$ in 2001, a clear difference in Cd intracellular partitioning in N. acuminata among sites was observed. At one of the reference sites, Great Kills Harbor, nearly $80 \%$ of Cd whole body burden in polychaetes was partitioned to the trophically available metal (TAM) compartment, whereas only $30 \%$ was partitioned to TAM at one of the AK sites, Main Creek, resulting in a similar concentration of Cd associated with TAM $\left(\sim 0.25 \mu \mathrm{g} \cdot \mathrm{g}^{-1}\right)$ at these sites. In 2004, however, the proportions of TAM-Cd in N. acuminata in AK increased (TAM-Cd $=\sim 45 \%$ ), as the concentrations of sediment-associated Cd decreased ( 1.1 to $2.9 \mu \mathrm{g} \cdot \mathrm{g}^{-1}$, Table 1$)$. This differential Cd partitioning suggests that $N$. acuminata in polluted sites may sequester increasingly more Cd into insoluble granules (not part of TAM), as $\mathrm{Cd}$ in the environment increases. The preferential sequestration to insoluble granules has also been observed in other annelid species in chronically polluted habitats (e.g., Berthet et al., 2003; Wallace et al., 1998). The exposure-dependent 'detoxification strategy shift' to granules in benthic invertebrates appears to reflect bioavailability of sediment-bound metals (Ballan-Dufrançais et al., 2001; Berthet et al., 2003). Granules are more durable and less likely to be recycled during cellular cycling than other subcellular components such as metal-binding proteins (Rainbow et al., 2004; Wallace et al., 1998). The sequestration into granules may thus be more efficient in detoxifying metals than metal-binding proteins, allowing organisms to tolerate an elevated level of metals in the environment (Wallace et al., 1998).

Unlike N. acuminata, the proportions of Cd partitioned to TAM were fairly uniform ( 40\%) in $P$. pugio across sites, and Cd concentration in TAM consistently increased with Cd whole body burden. This differential intracellular partitioning between $N$. acuminata and P. pugio may be due to the difference in feeding mode between these invertebrates (a deposit-feeder vs. an 
omnivore). As a deposit-feeder, N. acuminata is likely to ingest a considerable amount of sediments to extract sufficient organic carbon. As a result, these polychaetes may have been exposed to more sediment-bound Cd (incidentally, whole body burdens in N. acuminata were more than twice as much as those in $P$. pugio at most of the study sites) and have developed higher tolerance to $\mathrm{Cd}$ than $P$. pugio in AK.

Despite considerable differences in Cd trophic availability from invertebrate prey among sites, $\mathrm{Cd}$ bioaccumulation in mummichogs varied surprisingly little. Whole body burdens of Cd in mummichogs were strongly associated with the trophically available fraction of Cd (TAM[Cd]) only in P. pugio in 2004; no relationship between TAM-[Cd] in N. acuminata and Cd whole body burdens in mummichogs was found. In general, many fishes are known to efficiently eliminate a large amount of Cd ingested with the diet (e.g., Harrison and Curtis, 1992; Seebaugh et al., 2005). Previous feeding experiments using the reference population (Lemon Creek) have demonstrated that mummichogs are able to eliminate more than $90 \%$ of ingested Cd in P. pugio (Seebaugh et al., 2005). It is thus not surprising that the populations of mummichogs from chronically polluted sites can also eliminate the majority of trophically available Cd in ingested prey.

The relationship between $\mathrm{Cd}$ intracellular partitioning in $P$. pugio and $\mathrm{Cd}$ bioaccumulation in mummichogs may, however, provide some insights for differential Cd trophic availability to mummichogs in AK. For example, despite similar Cd whole body burdens in P. pugio from Mill Creek, Richmond Creek, and Main Creek, there was a substantial difference in TAM-Cd\% among these sites $(46.8,59.1$, and $73.1 \%$, respectively). This differential Cd trophic availability from $P$. pugio among sites was clearly reflected in the $\mathrm{Cd}$ bioaccumulation in mummichogs at these sites. Although there have been several experimental studies on the effects of metal 
detoxification in prey from chronically polluted habitats on metal trophic transfer to predators (e.g., Nott and Nicolaidou, 1994; Wallace et al., 1998), it is still unclear if detoxification strategies used by predators simultaneously influence metal trophic transfer (Goto and Wallace, 2009). Through the chronic exposure to trace metals, both prey and predators living in metalpolluted habitats may independently develop detoxification strategies, resulting in differential metal bioaccumulation in predators.

Compared to $\mathrm{Cd}$, the trophic transfer efficiency for $\mathrm{Pb}$ is not fully explored for many organisms. $\mathrm{Pb}$ is often inefficiently transferred in food chains (e.g., Chen and Folt, 2000; Mikac et al., 2001). However, a potential cause of low $\mathrm{Pb}$ trophic transfer efficiency has not been well understood. Rainbow et al. (2006a) have experimentally demonstrated that benthic invertebrate predators (Nereis virens and Palaemonetes varians) accumulated a considerably low amount of $\mathrm{Pb}$ from a deposit-feeding polychaete (Nereis diversicolor) collected from highly metal-polluted creeks in southwest England. The authors suggested that this low $\mathrm{Pb}$ trophic transfer efficiency may have been the result of its high affinity to insoluble granules (not part of TAM) in prey (Rainbow et al., 2006a). Metal-tolerant aquatic insects living in metal-polluted habitats, for example, sequester a substantial amount of $\mathrm{Pb}$ (more than $95 \%$ of whole body burdens) into an insoluble cellular component (Cain et al., 2000; Cain and Luoma, 1998). In the present study, similar results were also observed for both marine benthic invertebrate species (note that due to its low recovery rate, the concentration results for $\mathrm{Pb}$ need to be carefully considered). Although there were considerable differences in $\mathrm{Pb}$ whole body burdens between $P$. pugio and $N$. acuminata, in general, the proportion of $\mathrm{Pb}$ associated with TAM (TAM-Pb\%) gradually decreased from low to high $\mathrm{Pb}$-polluted sites (i.e., a reduction in $\mathrm{Pb}$ trophic availability to mummichogs). For example, despite its highest $\mathrm{Pb}$ whole body burden (in 2001), TAM-Pb\% in 
N. acuminata from Main Creek was the lowest among sites. Furthermore, despite their similar $\mathrm{Pb}$ whole body burdens $\left(\sim 0.23 \mu \mathrm{g} \cdot \mathrm{g}^{-1}\right)$, TAM-Pb\% in $P$. pugio from Main Creek was twice as much as that in shrimp from Richmond Creek (53.7\% vs. 27.2\%, respectively). This differential Pb intracellular partitioning in $P$. pugio was clearly reflected in $\mathrm{Pb}$ bioaccumulation in mummichogs from these sites (Main Creek: $0.94 \mu \mathrm{g} \cdot \mathrm{g}^{-1}$ vs. Richmond Creek: $0.21 \mu \mathrm{g} \cdot \mathrm{g}^{-1}$ ). The relationships between intracellular partitioning of non-essential metals in P. pugio and whole body burdens in mummichogs observed in the current study may thus explain certain differential metal bioaccumulation patterns in mummichogs (i.e., prey-driven bioreduction of metals in the food chain) in AK.

Unlike $\mathrm{Cd}$ and $\mathrm{Pb}$, intracellular partitioning of essential metals, $\mathrm{Cu}$ and $\mathrm{Zn}$, in both invertebrate prey species varied relatively little among sites. Despite substantially elevated levels of these metals in sediments at one of the AK sites, Mill Creek (Zn: 3 to 5-fold and Cu: 4 to 16fold more than the other sites), the variability in $\mathrm{Cu}$ and $\mathrm{Zn}$ associated with TAM in both $P$. pugio and $N$. acuminata was generally low among sites. This low variability among sites as well as relatively high TAM-Cu\% and TAM-Zn\% suggest that these macroinvertebrates may be able to regulate or at least tolerate these metals in AK. Similar results have also been observed in other marine and freshwater organisms (e.g., Berthet et al., 2003). Furthermore, high TAM-[Cu] in $P$. pugio observed in the current study is also likely to be associated with $\mathrm{Cu}$ requirement in haemocyanin by crustaceans (Rainbow, 1993; White and Rainbow, 1985).

With the exception of $\mathrm{Cu}$ in fish from Neck Creek in 2001, $\mathrm{Cu}$ and $\mathrm{Zn}$ bioaccumulation in mummichogs also varied little among populations $\left(\sim 10 \mu \mathrm{g} \mathrm{Cu} \cdot \mathrm{g}^{-1}\right.$ and $\sim 150 \mu \mathrm{g} \mathrm{Zn} \cdot \mathrm{g}^{-1}$, respectively). In spite of a highly elevated trophic availability (i.e., TAM-[Cu]) from $P$. pugio, the majority of ingested $\mathrm{Cu}$ may have been efficiently eliminated from mummichogs. Weis and 
Weis (1999) have demonstrated in a field transplant experiment that, compared to crustaceans such as P. pugio, mummichogs accumulated substantially lower $\mathrm{Cu}$ after three months. In contrast, both the AK and reference populations of mummichogs accumulated a substantial amount of $\mathrm{Zn}$. Compared to other metals including $\mathrm{Cu}$, a large amount of $\mathrm{Zn}$ in mummichogs is usually deposited in calcified structures such as scales (Sauer and Watabe, 1989), suggesting that the temporary deposition of excess $\mathrm{Zn}$ in calcified structures may be a detoxification strategy for fish.

\section{Conclusions}

Experimental studies on metal trophic transfer are often conducted using a naïve population of predators that have not been exposed to elevated levels of trace metals in their natural habitats (e.g., Reinfelder and Fisher, 1994; Seebaugh and Wallace, 2004). As both prey and predators are chronically exposed to trace metals in metal-polluted habitats, they may independently develop differential detoxification strategies. Directly extrapolating a relationship established from laboratory experiments may thus not be applicable to metal trophic transfer and bioaccumulation in the field setting. There is an urgent need to synthesize experimental findings and field observations to understand mechanisms involved in trace metal pollution in coastal ecosystems. The results of the present study suggest that metal intracellular partitioning within prey may be partially responsible for metal trophic availability to a predator in metal-polluted habitats. However, there was also evidence that some predator-dependent processes (e.g., digestive processes) may have offset differential trophic availabilities from prey (e.g., Cd bioaccumulation in mummichogs in 2001) (Goto and Wallace, 2009). Moreover, the present study also indicated the temporal differences observed in sediment-associated metal concentrations appeared to result 
in complex cascading effects on benthic invertebrates and fish (e.g., prey species-specific shifts in metal storage patterns). Further studies incorporating larger temporal as well as spatial data still need to be conducted to understand the importance of both prey- and predator- dependent processes to assess trace metal pollution in coastal ecosystems (Goto and Wallace, 2009; Rainbow et al., 2007).

\section{Acknowledgements}

This project was supported in part by PSC-CUNY Research Award and the Graduate Center, the City University of New York under the Doctoral Student Research Grant Program. We greatly appreciate field and laboratory assistance provided by D. Seebaugh, M. Perez, J. Khoury, A. Bernick, A. Estephan, M. Murphy, A. Ferretti, and the Interstate Environmental Commission laboratory, as well as useful comments provided by R.R. Veit, J.W. Rachlin, J.R. Waldman, P. Weis, and two anonymous reviewers.

\section{References}

Baines, S.B., Fisher, N.S., Stewart, R., 2002. Assimilation and retention of selenium and other trace elements from crustacean food by juvenile striped bass (Morone saxatilis). Limnol. Oceanogr. 46, 646-655.

Ballan-Dufrançais, C., Jeantet, A.Y., Geffard, A., Amiard, J.C., Amiard-Triquet, C., 2001. Cellular and tissular distribution of copper in an intrasedimentary bivalve, the Baltic clam Macoma balthica, originating from a clean or a metal-rich site. Can. J. Fish. Aquat. Sci. 58, 1964-1974.

Berthet, B., Mouneyrac, C., Amiard, J.C., Amiard-Triquet, C., Berthelot, Y., Hen, A.L., Mastain, O., Rainbow, P.S., Smith, B.D., 2003. Accumulation and soluble binding of cadmium, copper, and zinc in the polychaete Hediste diversicolor from coastal sites with different trace metal bioavailabilities. Arch. Environ. Contam. Toxicol. 45, 468-478.

Bopp, R.F., Chillrud, S.N., Shuster, E., Simpson, H.J., 2006. Contaminant chronologies from Hudson River sedimentary records. In: Levinton, J.S., Waldman, J.R. (Eds.), The Hudson River Estuary. Cambridge University Press, New York, pp. 383-397. 
Buchwalter, D.B., Cain, D.J., Clements, W.H., Luoma, S.N., 2007. Using biodynamic models to reconcile differences between laboratory toxicity tests and field biomonitoring with aquatic insects. Environ. Sci. Technol. 41, 4821-4828.

Cain, D.J., Carter, J.L., Fend, S.V., Luoma, S.N., Alpers, C.N., Taylor, H.E., 2000. Metal exposure in a benthic macroinvertebrate, Hydropsyche californica, related to mine drainage in the Sacramento River. Can. J. Fish. Aquat. Sci. 57, 380-390.

Cain, D.J., Luoma, S.N., 1998. Metal exposures to native populations of the caddisfly Hydropsyche (Trichoptera: Hydropsychidae) determined from cytosolic and whole body metal exposures. Hydrobiologia 386, 103-117.

Campbell, P.G.C., Giguere, A., Bonneris, E., Hare, L., 2005. Cadmium-handling strategies in two chronically exposed indigenous freshwater organisms--the yellow perch (Perca flavescens) and the floater mollusc (Pyganodon grandis). Aquat. Toxicol. 72, 83-97.

Chen, C.Y., Folt, C.L., 2000. Bioaccumulation and diminution of arsenic and lead in a freshwater food web. Environ. Sci. Technol. 34, 3878-3884.

Cheung, M., Wang, W.-X., 2005. Influence of subcellular metal compartmentalization in different prey on the transfer of metals to a predatory gastropod. Mar. Ecol. Prog. Ser. 286, 155166.

Clements, W.H., 1997. Effects of contaminants at higher levels of biological organization in aquatic ecosystems. Rev. Toxicol. 1, 107-146.

Clements, W.H., Rees, D.E., 1997. Effects of heavy metals on prey abundance, feeding habits, and metal uptake of brown trout (Salmo trutta) in the Arkansas River, Colorado. Trans. Am. Fish. Soc. 126, 774-785.

Crawford, D.W., Bonnevie, N.L., Gillis, C.A., Wenning, R.J., 1994. Historical changes in the ecological health of the Newark Bay Estuary, New Jersey. Ecotoxicol. Environ. Safety 29, 276303.

Farag, A.M., Woodward, D.F., Goldstein, J.N., E., M., Hogstrand, C., T., B.F., 1999. Dietary effects of metals-contaminated invertebrates from the Coer d'Alene River, Idaho, on cutthroat trout. Trans. Am. Fish. Soc. 128, 578-592.

Goto, D., 2009. Impacts of habitat degradation on Fundulus heteroclitus (Linnaeus) in urban tidal salt marshes in New York. Ph.D. Dissertation, City University of New York, New York NY.

Goto, D., Wallace, W.G., 2009. Influences of prey- and predator- dependent processes on cadmium and methylmercury trophic transfer to mummichogs (Fundulus heteroclitus). Can. J. Fish. Aquat. Sci. 66, 836-846. 
Griscom, S.B., Fisher, N.S., Luoma, S.N., 2002. Kinetic modeling of Ag, Cd and Co bioaccumulation in the clam Macoma balthica: Quantifying dietary and dissolved sources. Mar. Ecol. Prog. Ser. 240, 127-141.

Harrison, S.E., Curtis, P.J., 1992. Comparative accumulation efficiency of ${ }^{109}$ cadmium from natural food (Hyalella azteca) and artificial diet by rainbow trout (Oncorhynchus mykiss). Bull. Environ. Contam. Toxicol. 49, 757-764.

Klerks, P.L., Bartholomew, P.R., 1991. Cadmium accumulation and detoxification in a Cdresistant population of the oligochaete Limnodrilus hoffmeisteri. Aquat. Toxicol. 19, 97-112.

Klerks, P.L., Weis, J.S., 1987. Genetic adaptation to heavy metals in aquatic organisms: A review. Environ. Pollut. 45, 173-205.

Kneib, R.T., Stiven, A.E., Haines, E.B., 1980. Stable carbon isotope ratios in Fundulus heteroclitus (L.) muscle tissue and gut contents from a North Carolina Spartina marsh. J. Exp. Mar. Biol. Ecol. 46, 89-98.

Kneib, R.T., Wagner, S.L., 1994. Nekton use of vegetated marsh habitats at different stages of tidal inundation. Mar. Ecol. Prog. Ser. 106, 227-238.

Luoma, S.N., 1977. Detection of trace contaminant effects in aquatic ecosystems. J. Fish. Res. Board Can. 34, 436-439.

Luoma, S.N., 1996. The developing framework of marine ecotoxicology: Pollutants as a variable in marine ecosystems? J. Exp. Mar. Biol. Ecol. 200, 29-55.

Martin, C.A., Luoma, S.N., Cain, D.J., Buchwalter, D.B., 2007. Cadmium ecophysiology in seven stonefly (Plecoptera) species: Delineating sources and estimating susceptibility. Environ. Sci. Technol. 41, 7171-7177.

Mason, A.Z., Jenkins, K.D., 1995. Metal detoxification in aquatic organisms. In: Tessier, A., Turner, D.R. (Eds.), Metal speciation and bioavailability in aquatic systems. John Wiley \& Sons, Chichester, pp. 479-609.

Mikac, N., Brancia, M., Harrison, R.M., 2001. Total and organic lead distribution in water, sediment and organisms from the Eastern Adriatic. Chem. Spec. Bioavail. 13, 121-128.

Mouneyrac, C., Mastain, O., Amiard, J.C., Amiard-Triquet, C., Beaunier, P., Jeantet, A.-Y., Smith, B.D., Rainbow, P.S., 2003. Trace-metal detoxification and tolerance of the estuarine worm Hediste diversicolor chronically exposed in their environment. Mar. Biol. 143, 731-744.

Ni, I.H., Wang, W.X., Tam, Y.K., 2000. The transfer of Cd, Cr and $\mathrm{Zn}$ from zooplankton prey to mudskipper (Periophthalmus cantonensis) and glassy (Ambassis urotaenia) fishes. Mar. Ecol. Prog. Ser. 194, 203-211.

Nixon, S.W., Oviatt, C.A., 1973. Ecology of a New England salt marsh. Ecol. Monogr. 43, 463498. 
Nott, J.A., Nicolaidou, A., 1994. Variable transfer of detoxified metals from snails to hermit crabs in marine food chains. Mar. Biol. 120, 369-377.

Perceval, O., Couillard, Y., Pinel-Alloul, B., Giguere, A., Campbell, P.G.C., 2004. Metalinduced stress in bivalves living along a gradient of Cd contamination: Relating sub-cellular metal distribution to population-level responses. Aquat. Toxicol. 69, 327-345.

Rainbow, P.S., 1993. The significance of trace metal concentrations in marine invertebrates. In: Dallinger, R., Rainbow, P.S. (Eds.), Ecotoxicology of metals in invertebrates. Lewis Publishers, Chelsea, USA, pp. 3-23.

Rainbow, P.S., Amiard, J.C., Amiard-Triquet, C., Cheung, M.S., Zhang, L., Zhong, H., Wang, W.X., 2007. Trophic transfer of trace metals: subcellular compartmentalization in bivalve prey, assimilation by a gastropod predator and in vitro digestion simulations. Mar. Ecol. Prog. Ser. $348,125-138$.

Rainbow, P.S., Geffard, A., Jeantet, A.Y., Smith, B.D., Amiard, J.C., Amiard-Triquet, C., 2004. Enhanced food-chain transfer of copper from a diet of copper-tolerant estuarine worms. Mar. Ecol. Prog. Ser. 271, 183-191.

Rainbow, P.S., Poirier, L., Smith, B.D., Brix, K.V., Luoma, S.N., 2006a. Trophic transfer of trace metals from the polychaete worm Nereis diversicolor to the polychaete $N$. virens and the decapod crustacean Palaemonetes varians. Mar. Ecol. Prog. Ser. 321, 167-181.

Rainbow, P.S., Poirier, L., Smith, B.D., Brix, K.V., Luoma, S.N., 2006b. Trophic transfer of trace metals: Subcellular compartmentalization in a polychaete and assimilation by a decapod crustacean. Mar. Ecol. Prog. Ser. 308, 91-100.

Reinfelder, J.R., Fisher, N.S., 1994. The retention of elements absorbed by juvenile fish (Menidia menidia, M. beryllina) from zooplankton prey. Limnol. Oceanogr. 39, 1783-1789.

Roesijadi, G., 1992. Metallothioneins in metal regulation and toxicity in aquatic animals. Aquat. Toxicol. 22, 81-114.

Sauer, G.R., Watabe, N., 1989. Temporal and metal-specific patterns in the accumulation of heavy metals by the scales of Fundulus heteroclitus. Aquat. Toxicol. 14, 233-248.

Seebaugh, D.R., Goto, D., Wallace, W.G., 2005. Bioenhancement of cadmium transfer along a multi-level food chain. Mar. Environ. Res. 59, 473-491.

Seebaugh, D.S., Wallace, W.G., 2004. Importance of metal-binding proteins in the partitioning of $\mathrm{Cd}$ and $\mathrm{Zn}$ as trophically available metal (TAM) in the brine shrimp Artemia franciscana. Mar. Ecol. Prog. Ser. 272, 215-230.

Sokal, R.R., Rohlf, F.J., 1995. Biometry. W.H. Freeman and Company, New York.

Wallace, W.G., Lopez, G.R., 1997. Bioavailability of biologically sequestered cadmium and the implications of metal detoxification. Mar. Ecol. Prog. Ser. 147, 149-157. 
Wallace, W.G., Lopez, G.R., Levinton, J.S., 1998. Cadmium resistance in an oligochaete and its effect on cadmium trophic transfer to an omnivorous shrimp. Mar. Ecol. Prog. Ser. 172, 225237.

Wallace, W.G., Luoma, S.N., 2003. Subcellular compartmentalization of Cd and Zn in two bivalves. II. Significance of trophically available metal (TAM). Mar. Ecol. Prog. Ser. 257, 125137.

Wang, W.-X., 2002. Interactions of trace metals and different marine food chains. Mar. Ecol. Prog. Ser. 243, 295-309.

Ward, A., 2002. Metal contamination in sediment collected from the Arthur Kill, Staten Island, NY. MS Thesis, College of Staten Island, Staten Island, NY.

Weis, J.S., Samson, J., Zhou, T., Skurnick, J., Weis, P., 2001. Prey capture ability of mummichogs (Fundulus heteroclitus) as a behavioral biomarker for contaminants in estuarine systems. Can. J. Fish. Aquat. Sci. 58, 1442-1452.

Weis, P., Weis, J.S., 1999. Accumulation of metals in consumers associated with chromated copper arsenate-treated wood panels. Mar. Environ. Res. 48, 73-81.

White, S.L., Rainbow, P.S., 1985. On the metabolic requirements for copper and zinc in molluscs and crustaceans. Mar. Environ. Res. 16, 215-229.

Woodward, D.F., Farag, A.M., Bergman, H.L., DeLonay, A.J., Little, E.E., Smith, C.E., Barrows, F.T., 1995. Metals-contaminated benthic invertebrates in the Clark Fork River, Montana: Effects on age-0 brown trout and rainbow trout. Can. J. Fish. Aquat. Sci. 52, 19942004.

Zhang, L., Wang, W.-X., 2006. Significance of subcellular metal distribution in prey in influencing the trophic transfer of metals in a marine fish. Limnol. Oceanogr. 51, 2008-2017.

\section{Figure captions}

Fig. 1. Map of study sites in the Arthur Kill (Mill Creek, Richmond Creek, Main Creek, and Neck Creek), New York Harbor (Great Kills Harbor) and Raritan Bay (Lemon Creek), New York.

Fig. 2. Relationships between Cd whole body burdens (WB-[Cd], $\mu \mathrm{g} \cdot \mathrm{g}^{-1}$ ) and concentrations of Cd associated with TAM (TAM-[Cd], $\mu \mathrm{g} \cdot \mathrm{g}^{-1}$ ) or percentages of Cd associated with TAM (TAM$\mathrm{Cd} \%$ ) in two benthic macroinvertebrate prey species. Palaemonetes pugio - (a) TAM-[Cd] in 2001, (b) TAM-[Cd] in 2004, (c) TAM-Cd\% in 2001, and (d) TAM-Cd\% in 2004. Nereis acuminata - (e) TAM-[Cd] in 2001, (f) TAM-[Cd] in 2004, (g) TAM-Cd\% in 2001, and (h) TAM-Cd $\%$ in 2004 . Error bars indicate \pm 1 SE. Solid lines indicate regression. Dashed lines indicate $95 \%$ confidence intervals. 
Fig. 3. Relationships between $\mathrm{Pb}$ whole body burdens (WB-[Pb], $\mu \mathrm{g} \cdot \mathrm{g}^{-1}$ ) and concentrations of $\mathrm{Pb}$ associated with TAM (TAM- $\mathrm{Pb}], \mu \mathrm{g} \cdot \mathrm{g}^{-1}$ ) or percentages of $\mathrm{Pb}$ associated with TAM (TAM$\mathrm{Pb} \%$ ) in two benthic macroinvertebrate prey species. Palaemonetes pugio - (a) TAM- $[\mathrm{Pb}]$ in 2001, (b) TAM-[Pb] in 2004, (c) TAM-Pb\% in 2001, and (d) TAM-Pb\% in 2004. Nereis acuminata - (e) TAM-[Pb] in 2001, (f) TAM-[Pb] in 2004, (g) TAM-Pb\% in 2001, and (h) $\mathrm{TAM}-\mathrm{Pb} \%$ in 2004 . Error bars indicate $\pm 1 \mathrm{SE}$. Solid lines indicate regression. Dashed lines indicate $95 \%$ confidence intervals.

Fig. 4. Relationships between $\mathrm{Cu}$ whole body burdens (WB- $[\mathrm{Cu}], \mu \mathrm{g} \cdot \mathrm{g}^{-1}$ ) and concentrations of $\mathrm{Cu}$ associated with TAM (TAM- $[\mathrm{Cu}], \mu \mathrm{g} \cdot \mathrm{g}^{-1}$ ) or percentages of Cd associated with TAM (TAM$\mathrm{Cu} \%$ ) in two benthic macroinvertebrate prey species Palaemonetes pugio - (a) TAM- $[\mathrm{Cu}]$ in 2001, (b) TAM-[Cu] in 2004, (c) TAM-Cu\% in 2001, and (d) TAM-Cu\% in 2004. Nereis acuminata - (e) TAM-[Cu] in 2001, (f) TAM- $[\mathrm{Cu}]$ in 2004, (g) TAM-Cu\% in 2001, and (h) TAM-Cu\% in 2004. Error bars indicate \pm 1 SE. Solid lines indicate regression. Dashed lines indicate $95 \%$ confidence intervals.

Fig. 5. Relationships between $\mathrm{Zn}$ whole body burdens (WB-[Zn], $\mu \mathrm{g} \cdot \mathrm{g}^{-1}$ ) and concentrations of $\mathrm{Zn}$ associated with TAM (TAM-[Zn], $\mu \mathrm{g} \cdot \mathrm{g}^{-1}$ ) or percentages of $\mathrm{Zn}$ associated with TAM (TAM$\mathrm{Zn} \%$ ) in two benthic macroinvertebrate prey species in 2001. Palaemonetes pugio - (a) TAM[Zn] and (b) TAM-Zn\%. Nereis acuminata - (c) TAM-[Zn] and (d) TAM-Zn\%. Error bars indicate \pm 1 SE. Solid lines indicate regression. Dashed lines indicate $95 \%$ confidence intervals. Samples for 2004 were not available.

Fig. 6. (a) Relationships between $\mathrm{Pb}$ whole body burdens (WB- $[\mathrm{Pb}]_{\text {fish }}, \mu \mathrm{g} \cdot \mathrm{g}^{-1}$ ) in mummichogs and concentrations of $\mathrm{Pb}$ associated with TAM (TAM- $\left.[\mathrm{Pb}]_{\text {prey }}, \mu \mathrm{g} \cdot \mathrm{g}^{-1}\right)(\boldsymbol{\nabla})$ or Pb whole body burdens (WB- $[\mathrm{Pb}]_{\text {prey }}, \mu \mathrm{g} \cdot \mathrm{g}^{-1}$ ) in Palaemonetes pugio (•) in 2001; and (b) Relationships between $\mathrm{Cd}$ whole body burdens (WB- $[\mathrm{Cd}]_{\text {fish }}, \mu \mathrm{g} \cdot \mathrm{g}^{-1}$ ) in mummichogs and concentrations of $\mathrm{Cd}$ associated with TAM (TAM- $\left.[\mathrm{Cd}]_{\text {prey }}, \mu \mathrm{g} \cdot \mathrm{g}^{-1}\right)(\boldsymbol{\nabla})$ or Cd whole body burdens (WB- $[\mathrm{Cd}]_{\text {prey }}, \mu \mathrm{g} \cdot \mathrm{g}^{-}$ $\left.{ }^{1}\right)$ in Palaemonetes pugio $(\bullet)$ in 2004. The solid lines indicate the least squares regression between (a) TAM- $[\mathrm{Pb}]_{\text {prey }}$ and WB- $[\mathrm{Pb}]_{\text {fish }}$, or (b) TAM- $[\mathrm{Cd}]_{\text {prey }}$ and WB- $[\mathrm{Cd}]_{\text {fish }}$. 


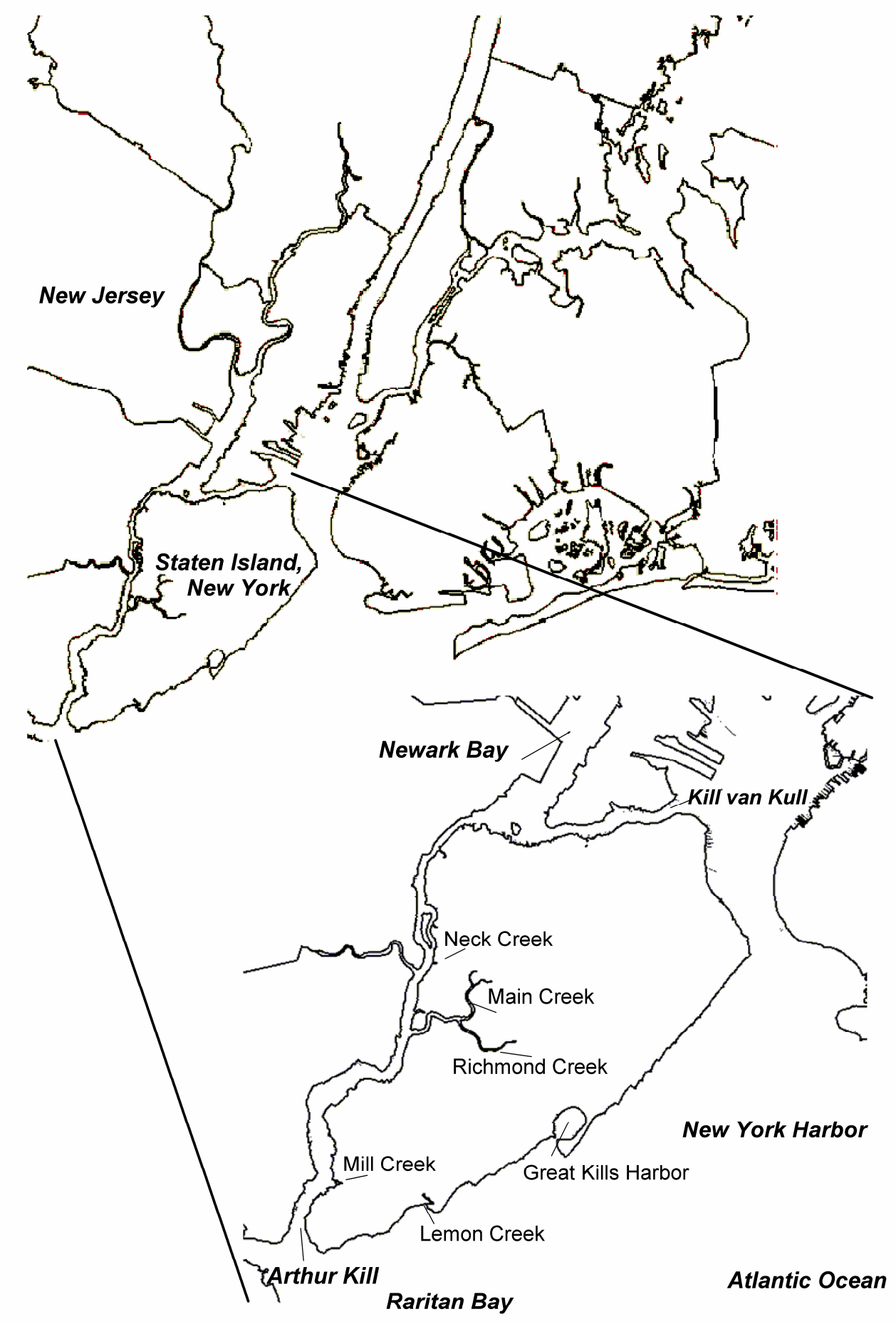


Palaemonetes pugio
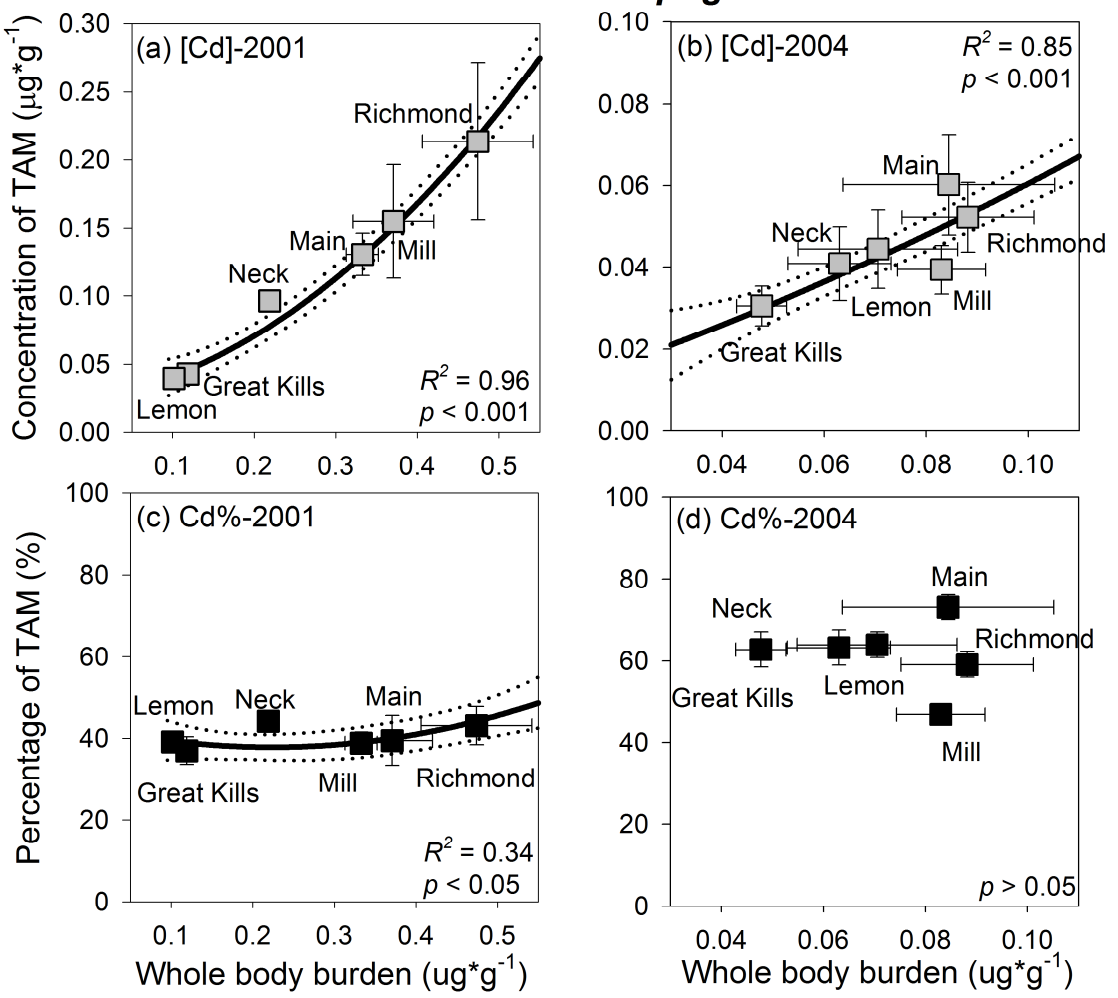

Nereis acuminata
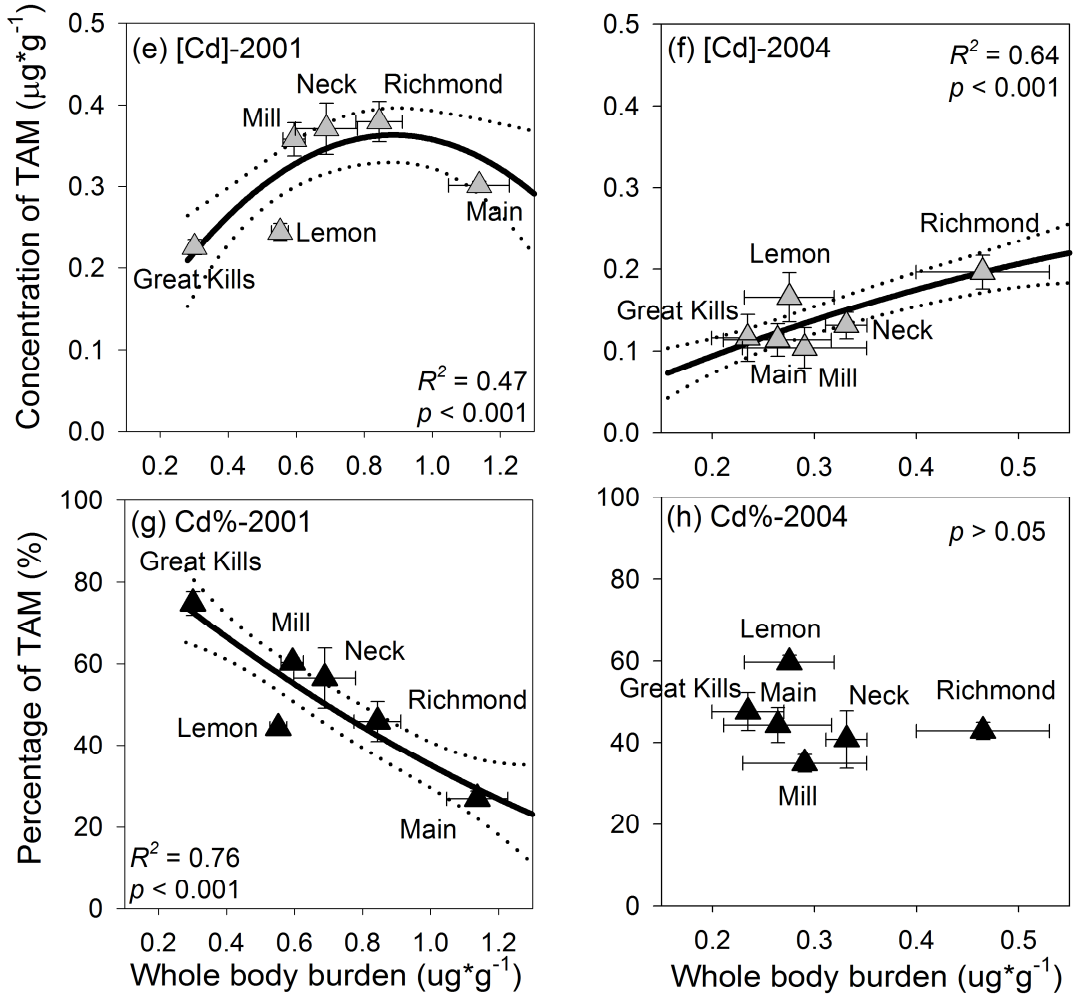
Palaemonetes pugio
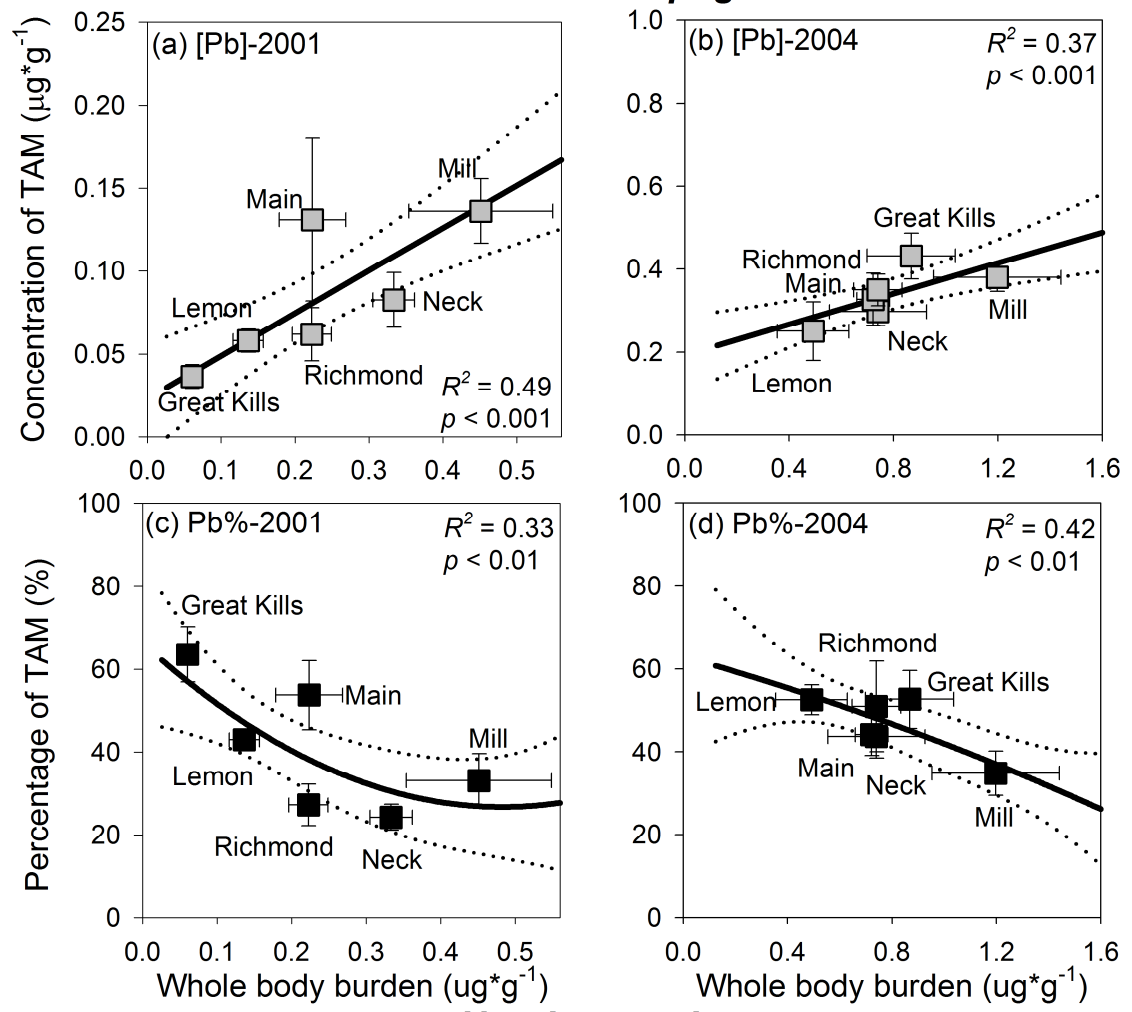

Nereis acuminata
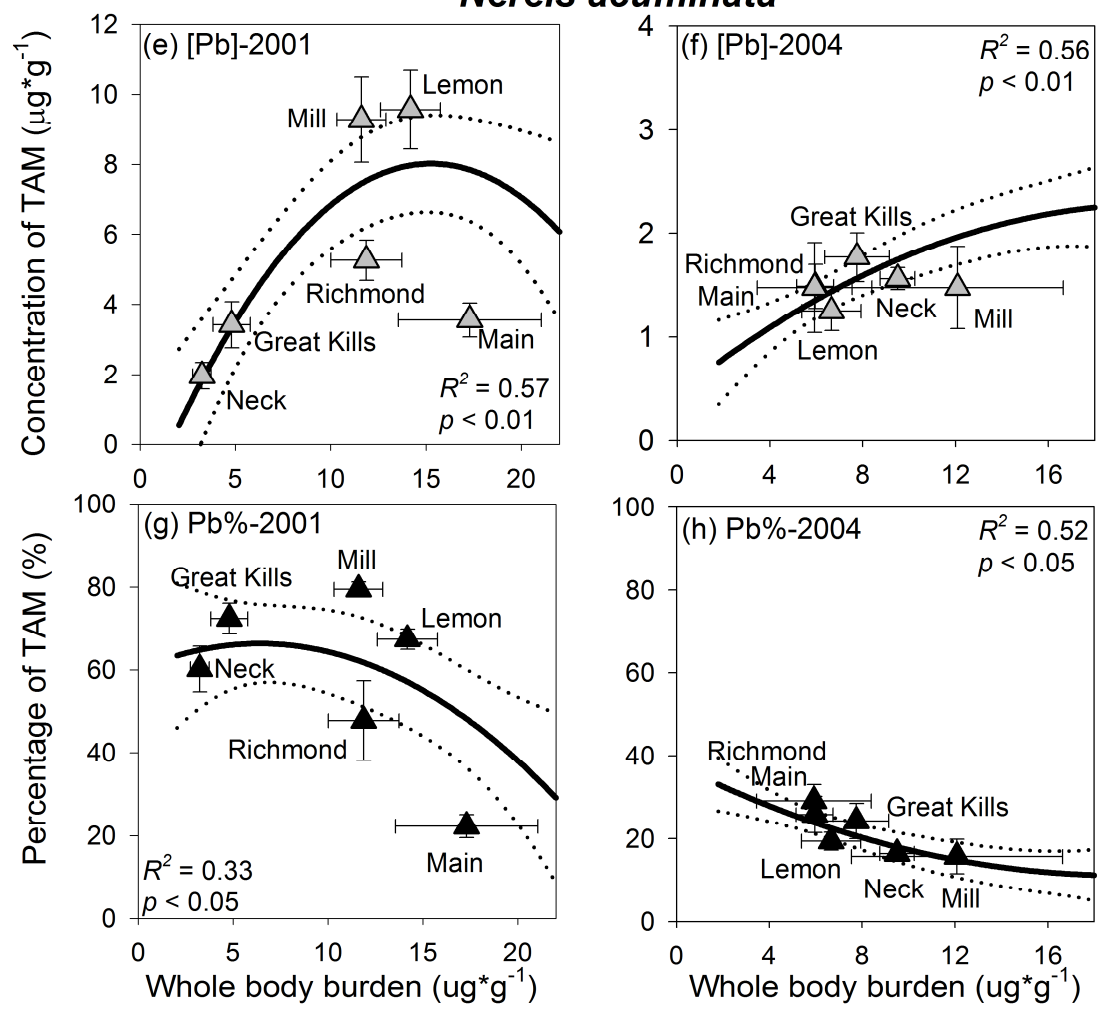

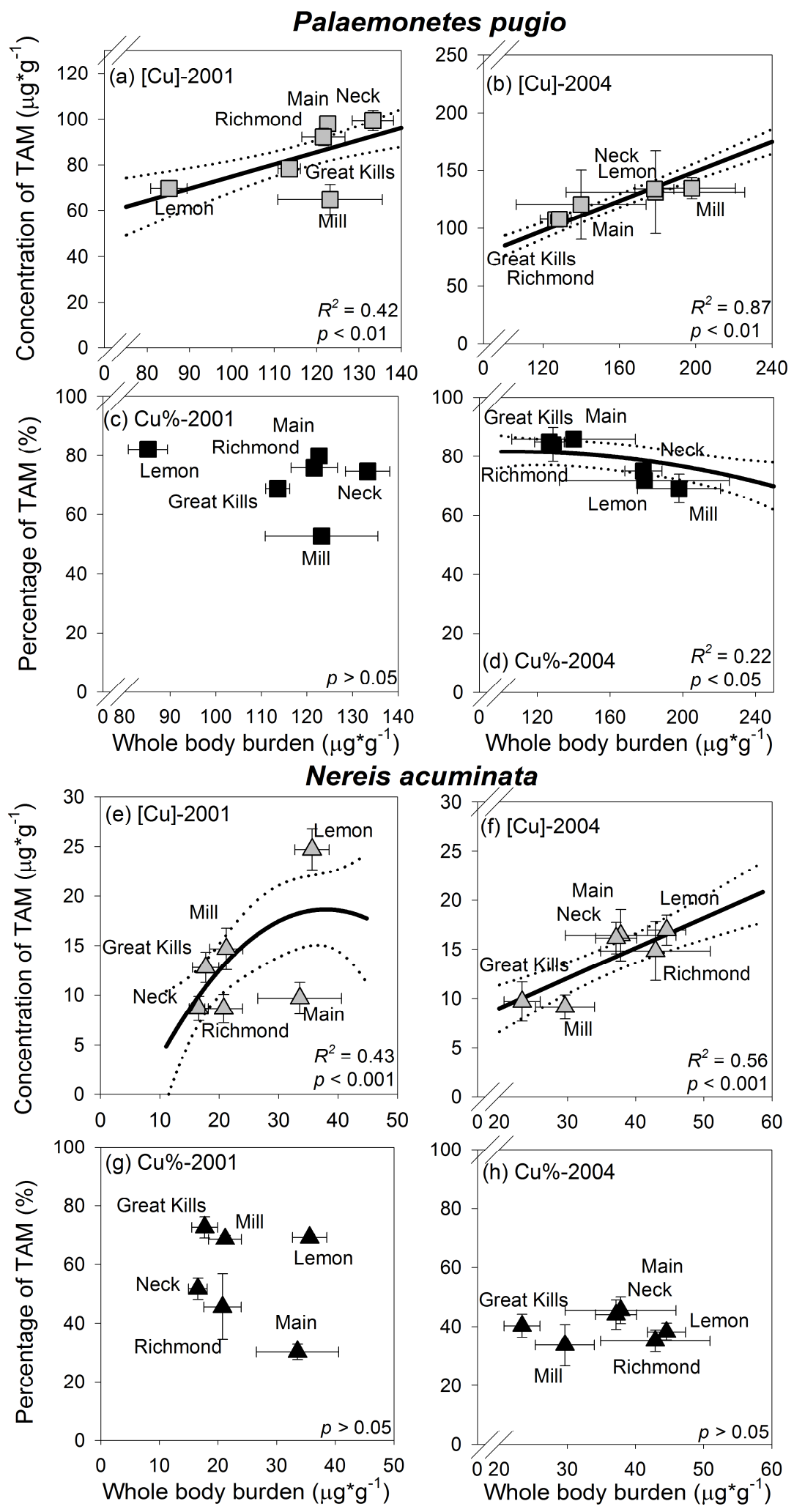
Palaemonetes pugio
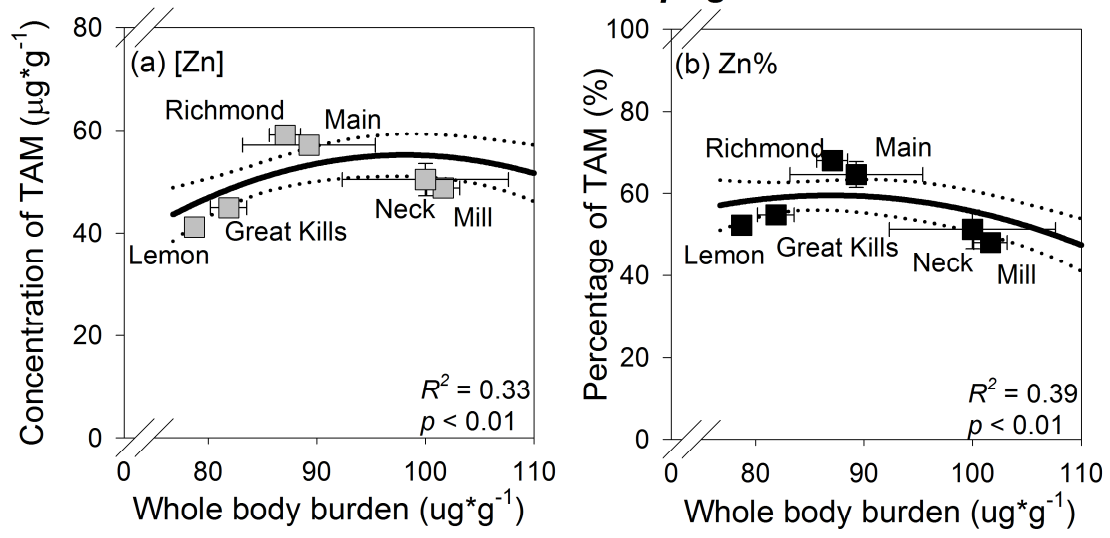

Nereis acuminata
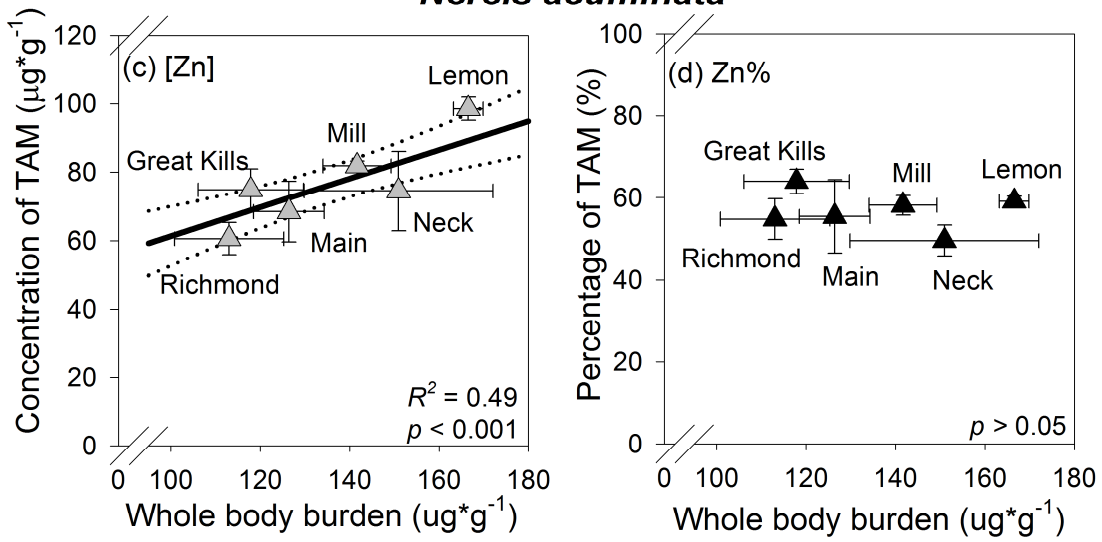

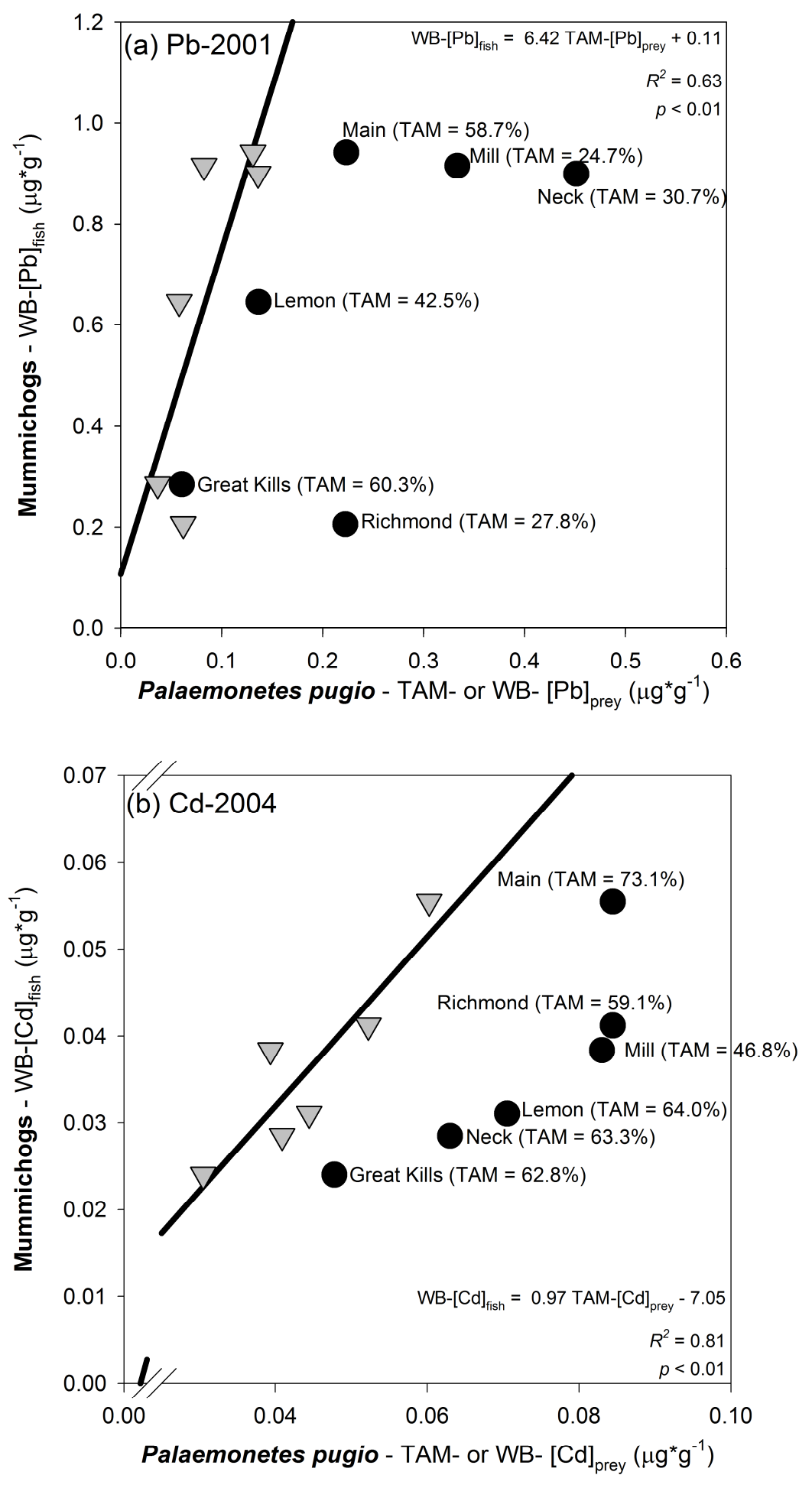
Table 1

Mean concentrations of metals $\left(\mu \mathrm{g} \cdot \mathrm{g}^{-1}\right)$ in sediments collected from the study sites in 2001 and $2004 \dagger$

\begin{tabular}{ccccccccccccc}
\hline & \multicolumn{10}{c}{ Study sites } \\
\cline { 2 - 13 } $\begin{array}{c}\text { Trace } \\
\text { metals } \\
\left(\mu \mathrm{g} \cdot \mathrm{g}^{-1}\right)\end{array}$ & \multicolumn{10}{c}{ Lemon Creek } & \multicolumn{1}{c}{$\begin{array}{c}\text { Great Kills } \\
\text { Harbor }\end{array}$} & \multicolumn{10}{c}{ Mill Creek } & \multicolumn{1}{c}{ Richmond Creek } & \multicolumn{1}{c}{ Main Creek } & Neck Creek \\
\hline & 2001 & 2004 & 2001 & 2004 & 2001 & 2004 & 2001 & 2004 & 2001 & 2004 & 2001 & 2004 \\
\hline $\mathrm{Cd}$ & 2.4 & 1.2 & - & 1.1 & 6.0 & 2.9 & 5.7 & 1.6 & 5.2 & 2.9 & 2.8 & 1.1 \\
$\mathrm{Cu}$ & 91.3 & 124.8 & - & 92.2 & 1483.5 & 911.5 & 266.9 & 99.7 & 294.4 & 216.5 & 238.8 & 152.5 \\
$\mathrm{~Pb}$ & 27.5 & 83.9 & - & 98.7 & 402.8 & 655.5 & 63.8 & 91.9 & 58.0 & 171.3 & 80.4 & 214.7 \\
$\mathrm{Zn}$ & 107.8 & 220.5 & - & 188.4 & 555.9 & 1193.3 & 293.0 & 289.0 & 336.7 & 410.9 & 165.8 & 339.0 \\
\hline
\end{tabular}

$\dagger$ Sources of the data: Ward (2002) for 2001 and Goto (2009) for 2004.

*Sediment samples from Great Kills Harbor were not available in 2001. 
Table 2

Mean whole body burdens of $\mathrm{Cd}, \mathrm{Pb}, \mathrm{Cu}$, and $\mathrm{Zn}\left(\mu \mathrm{g} \cdot \mathrm{g}^{-1}\right)$ in mummichogs collected from the study sites in 2001 and 2004

\begin{tabular}{|c|c|c|c|c|c|c|c|c|c|c|}
\hline Study sites & \multirow[t]{7}{*}{2001} & $\mathrm{Cd}$ & $\mathrm{Pb}$ & $\mathrm{Cu}$ & $\mathrm{Zn}$ & \multirow[t]{7}{*}{2004} & $\mathrm{Cd}$ & $\mathrm{Pb}$ & $\mathrm{Cu}$ & $\mathrm{Zn}$ \\
\hline Lemon Creek & & $0.06_{B}$ & $0.65_{\mathrm{AB}}$ & $6.98_{\mathrm{A}}$ & $138.16_{\mathrm{B}}$ & & 0.03 & $0.66_{\mathrm{A}}$ & 16.10 & 146.77 \\
\hline Great Kills Harbor & & $0.10_{\mathrm{A}}$ & $0.28_{\mathrm{A}}$ & $7.48_{\mathrm{A}}$ & $158.12_{\mathrm{AB}}$ & & 0.02 & $0.60_{\mathrm{A}}$ & 8.37 & 173.95 \\
\hline Mill Creek & & $0.08_{\mathrm{AC}}$ & $0.90_{\mathrm{B}}$ & $10.66_{\mathrm{A}}$ & $161.67_{\mathrm{AB}}$ & & 0.05 & $1.45_{\mathrm{B}}$ & 10.74 & 182.47 \\
\hline Richmond Creek & & $0.03_{\mathrm{D}}$ & $0.21_{\mathrm{A}}$ & $7.11_{\mathrm{A}}$ & $143.56_{\mathrm{B}}$ & & 0.04 & $0.58_{\mathrm{A}}$ & 9.88 & 178.01 \\
\hline Main Creek & & $0.09_{\mathrm{AC}}$ & $0.94_{B}$ & $7.75_{\mathrm{A}}$ & $143.93_{\mathrm{B}}$ & & 0.03 & $0.62_{\mathrm{A}}$ & 8.96 & 124.02 \\
\hline Neck Creek & & $0.06_{\mathrm{BC}}$ & $0.92_{\mathrm{B}}$ & $18.50_{\mathrm{B}}$ & $193.70_{A}$ & & 0.02 & $0.60_{\mathrm{A}}$ & 11.53 & 153.97 \\
\hline
\end{tabular}

Different letters indicate statistically significant difference among sites (one-way ANOVA followed by Tukey's HSD test, $p<0.05)$. 